\title{
Relative Age Effect on basketball: implications for the selection of successful players \\ Efecto de la edad relativa en el baloncesto: implicaciones para la selección de jugadores exitosos
}

\author{
Larissa Fernanda Porto Maciel, Mônica Cristina Flach, Raquel Krapp do Nascimento, Eduardo José Dallegrave, \\ Juarez Vieira do Nascimento, Alexandra Folle \\ State U niversity of SantaCatarina (Brasil), Federal U niversity of Santa Catarina (Brasil)
}

\begin{abstract}
The RelativeAge Effect has been the subject of study by researchers who seek to understand sports performance. This study aimed to analyze the prevalence of relative age effect (RAE) in basketball players, verifying whether early-birth players and the features of the place they inserted affect probable recruitment for athletic teams. The sample was comprised 1,455 players within 9 and 19-year-old. Variables included birth semester, gender, sports category, number of recruitments, geographical region. Datawere analyzed using descriptive statistics and binary logistic regression model. The resultsfound that early-birth players had a better chance to be recruited for state athl etic teamsu13 than late-birth ones. Players 15 and u17 had similar chances. Further, u13 and u15 players linked to the northern region for Brazil and in cities with very high Human Development Index (HDI) and medium-sized cities had a better recruitment chance for state team. Results may be employed by coaches, recruiters and headhunters, since variables associated to RAE may affect the state team and players' performance throughout the process of sports formation. Removing the influence of relative age-related differences is predicted to improve the accuracy of identifying skilled players.
\end{abstract}

Keywords: Athlete Development, SportsTalent,Youth Categories, PerformanceAnalyses.

Resumen. El efecto de la edad relativa (RAE) ha sido objeto de estudio por parte de investigadores que buscan comprender el desempeño en el deporte. El presente estudio tuvo como objetivo analizar el predominio del efecto de la edad relativa (RAE) en jugadores de bal oncesto, verificando si los jugadores de nacimiento temprano y las características del lugar donde estaban insertos inciden en el probable reclutamiento para equipos deportivos. La muestra estuvo compuesta por 1.455 jugadores de entre 9 y 19 años. Las variables incluyeron semestre de nacimiento, género, categoría deportiva, número de reclutamientos, región geográfica. Los datos fueron anal izadosmediante estadísticadescriptivay modelo de regresión logística binaria. Los resultados encontrados demostraron que los jugadores de nacimiento temprano tenían mayores posibilidades de ser reclutados para equipos atléticos estatales sub13 que los de nacimiento tardío. Los jugadores sub15 y sub17 tuvieron oportunidades similares. Además, los jugadores sub13 y sub15 vinculados a la región norte de Brasil y en ciudades com al to Índice de D esarrollo Humano (IDH) y ciudades medianas, tuvieron mayores oportunidades de ser reclutados para el equipo estatal. Los resultados pueden ser empleados por entrenadores, reclutadores y cazatalentos, ya que las variables asociadas al RAE pueden afectar el desempeño del equipo estatal y de los jugadores a lo largo del proceso de formación deportiva. Se prevé que al eliminar la influencia de las diferencias relativas relacionadas con laedad mejorarála precisión en la identificación de jugadores habilidosos.

Palabras clave: Desarrollo del Atleta, Talento Deportivo, Categorías Juveniles, Análisis del Desempeño.

\section{Introduction}

The Relative Age Effect (RAE) has received a great deal of attention by researchers particularly in Sports Science (Jackson \& Comber, 2020; Rossing, Stentoft, Flattum, Côté \& Karbing, 2018). The effect among players may be perceived in the highly represented players born in the first six month of the year (first and second quarter), or early-birth players and a sub-

Fecha recepción: 02-10-20. Fecha de aceptación: 18-03-21

Eduardo José Dallegrave

edudallegrave@gmail.com representation of players born in the last six months of the year (third and fourth quarter), or late-birth players (Huertas, Ballester, Gines, Hamidi, M oratal \& Lupianez, 2019). Besides the effects associated with date of birth, the environment in which the player is may enhance or impair the access to opportunities and, consequently, chances for higher performance and visibility levels (Rossing et al., 2018; Valero, Pérez, Jaén \& Anta, 2020).

Although a great number of papers on RAE has been published worldwide, there is still a continuous need to understand excellence, performance and selection of player sof different ages, culturesand competitive levels, as it is an important field of investigation within the 
scientific community (Papadopoulou, Papadopoulou, Rosemann, Knechtle \& N ikolaidis, 2019). As far as one knows, even within the broadening of investigations on the theme, there is a lack of analyses on whether RAE and the characteristics of the sports context influence the probability of basketball players to be recruited for state sports teams (Baker \& Horton, 2004; Côté, Macdonald, Baker \& A bernethy, 2006; Carraco, Gallati, Massa, Loturco \& Abad, 2020).

In this context, the RAE has been extensively studied in different types of sports, such as ice hockey (Fumarco, Gibbs, Jarvis \& Rossi, 2017), baseball (Katsumata, 0 muro, Mitsukawa $\&$ Nakata, 2018), handball (Leonardo, Lizana, K rahenbühl \& Scaglia, 2018;W rang, Rossing, Diernaes, Hansan, Dalgaard-H ansen \& K arbing, 2018), volleyball (Papadopoulou et al., 2019), soccer (Bezuglov, Nikolaidis, Khaitin, U smanova, Luibushkina, Repetiuk \& Knechtle, 2019; Bidaurrazaga-Letona, Badiola, Granados, Lekue, Amado \& Gil; Huertas et al. , 2019; Jackson and Comber, 2020), basketball (Ibãnéz, Mazo, Nascimento \& García-Rubio 2018; Ribeiro Júnior, Lobão, O liveira, Vianna \& Werneck, 2020), athletics (Brustio, Kearney, Lupo, U ngureanu, Mulasso, Rainoldi $\&$ Boccia, 2019; Valero et al., 2020) and padel (M uñoz, González, Q uintana-García \& Peinado, 2021). The evidence found has revealed physical, maturational, and psychological differences between players born at the beginning of the year and players born at the end of the year.

However, the literature on RAE in youth basketball has shown different results according to the sample analyzed. In France, RAE has been detected in players u7 to $u 18$ of both genders (Delorme, Boiché \& Raspaud, 2010), very similar to that in Poland (u14 - u22) (Rubajczyk, Swierzko \& Rokita, 2017). In Brazil, RAE has been more prevalent in male players (u12 - u17) (O liveira, Ribeiro Júnior, Vianna \& W erneck, 2017; Ribeiro Júnior et al. , 2020), similar to results from Portugal (u14) (Arrieta, Torres-U nda, Gil \& Irazusta, 2016) and Spain (u16 and u18) (Arrieta et al., 2016; Ibãnéz et al., 2018).

Similar to other contexts, players' performance in sports is the result of a complex interaction between individual factors (date of birth, for instance) and milieu (place of birth or training) (Côté et al. , 2006; Huertas et al., 2019). Several sports modalities (ice hockey, basketball, soccer) group players into categories according to their age (Ibãnéz et al. . 2018; Ramos-Filho \& Ferreira, 2020). Although the method is necessary for better organization of sports competitions (Rubajczyk et al.,
2017), the age difference between players of the same sports category varies from physical and psychological maturity, to cognitive and social issues which may interfere in performance and competitions (O liveira et al., 2017; M endes et al. ,2021; Muñoz et al., 2021).

Evidence reported in the literature suggests that national, social and economic aspects related to demographic rates and the Human Development Index (HDI) of the place seem to condition the intrinsic and extrinsic motivation to practice sports (Tozetto, Rosa, Mendes, Galatti, Souza, Collet \& Silva, 2017). In this case, the HDI aims to represent a general measure of human development in several aspects, such as quality of life, education, and economics (PNUD, 2019). Such information can contribute to the understanding of possible influences of the context in the sports career of athletes (M endes et al., 2021), since the literature presents discrepancies with regard to the context and the best size of the environment in the training of players in different sports, countries and cultures (Rossing et al., 2018).

RAE and the place where players exercise their main sporting experiences seem to be strongly linked to the relevant skills and opportunities for performance in the sport. In spite of the above, it is not evident whether both factors interact and establish a synergic effect that benefits or disfavors players to attain higher training and competition levels. Similarly, due to lack of information and data from other countries, it is not evident whether the effect applies to different competitions levels (youth, adult, elite), social and demographic structures or whether it is restricted to specific contexts and cultures.

Very large cities, for example, offer high costs and distances for the displacement of players, but on the other hand, they stand out for providing better physical and human structure for sports development (Balish, Rainham \& Blanchard, 2015). In smaller cities, in turn, athletes receive more social support and experience less conflict with other people than larger city athletes (Baker \& Logan, 2007), but in contrast, they do not have access to better training and competition structures.

In the case of basketball, several studies have focused on the prevalence of RAE by analyzing distribution of births among the months of the year (Rubajczyk et al., 2017) or associating it to performance indexesaccording to specific positions of the sports modality (Ibãnéz et al., 2018), or physical and physiological characteristics (Arrieta et al., 2016; Ribeiro Júnior et al., 2020). W hen 
it comes to dealing with environmental factors, most studies have focused on the relationship between RAE and the players' place of birth (Baker et al. 2009; Tozetto et al., 2017), whilst few studies aimed at associating RAE and other environments (Balish \& Côté, 2013; Rossing et al., 2018), such as the place where players exercise their main sporting experiences as young people.

In spite of the possible influence of date of birth and training place in players' performance, to our best knowledge, there are no studies on the above theme comprising young basketball players of both genders, especially within the Brazilian context. Scarcity of research has triggered the investigation of the subject matter in current study. The study analyzes (a) the prevalence of RAE in basketball players to verify whether the semester of birth influences the probability of being recruited for state teams and (b) whether the characteristics of the place in which the players play (region, HDI, population) affect the same probability. The hypothesis raised from the extant literature (Ibãnéz et al., 2018; Tozetto et al., 2017) with regard to the predominance of early-birth players and their chances in being recruited for state teams. The study also aims at detecting players who, due to their more developed contexts, would have better chances of being recruited for state teams.

\section{M aterials and M ethods}

\section{Study Design and Partidpants}

Current transversal study comprised a sample of 1,455 players of both genders, aged between 9 and 19 years old (14.37 \pm 2.0 years) who took part in the Championship of the Basketball the State of Santa Catarina, Brazil, in 2018, organized by the Federação Catarinense de Basketball (FCB). In 2018, the competition had 43 teams ( 19 female and 22 maleteams) from all the regions of the state. The championship is traditionally organized into three stages: classificatory stage (turn and return); semifinals (the best qualified teams); and finals (four runners-up). In the case of state teams, relevant players in their sports categories may be recruited by coaches and chosen by the FCB to represent the state in leagues at regional and national levels, among which may be mentioned the Campeonato Sul-Brasileiro de Seleções [The Championship of Teamsfrom South Brazil] and the Campeonato Brasileiro de Base [Brazilian Championship] promoted by the Confederação Brasileira de Basketball [Brazilian Bas- ketball Confederation] (CBB). Players were classified and analyzed according to their respective categories in the competition, namely, u13 ( $n=588), u 15(n=435)$, $u 17(n=264)$ and $u 19(n=168)$.

\section{Data collection}

Data were retrieved from three document sources: (a) the official homepage of the FCB (https:/ / www. basket-fcb.com.br); (b) summaries of the games provides by FCB and (c) Brazilian Institute of Geography and Statistics (IBGE) (https:/ / www. ibge.gov.br/ ). As the information used was collected in public databases made available online, the present study did not need approval from the Ethics Committee, following the same logic of previous studies (Watie, Schorer \& Baker, 2015; O liveira et al. 2017; O liveira, Ribeiro Júnior et al., 2017).

Date limit for birth for the categories of participating clubs of the Santa Catarina Championship] is $1^{\text {st } ~ J a n u a r y ~}$ and semesters have been organized according to this cross-section. Variables for analysis included semester of birth ( $1^{\text {st }}$ semester: January, February, M arch, April, May and June; $2^{\text {nd }}$ semester: July, August, September, $O$ ctober, N ovember and December), gender (male and female), category (u13, u15, u17, u19), number of recruitments for state teams ( $u 13, u 15, u 17)$ and the region in the state of Santa Catarina to which players were linked (West, North, Serrana, Vale do Itajaí, Greater Florianópolis, South). Data on the demographic characteristics of the towns or cities (population and $\mathrm{HDI}$ ) to which players were linked was obtained from the IBGE homepage (2010 and 2018) (Table 1).

\begin{tabular}{|c|c|c|c|c|c|}
\hline \multirow{2}{*}{ Variables } & \multicolumn{5}{|c|}{ Categories } \\
\hline & U13 n(\%) & U15 n(\%) & U17 n(\%) & U19n(\%) & Total \\
\hline \multicolumn{6}{|l|}{ Gender } \\
\hline Female & $218(37.1)$ & $130(29.9)$ & $105(39.8)$ & $50(29.8)$ & $503(34.6)$ \\
\hline Male & $370(62.9)$ & $305(70.1)$ & $159(60.2)$ & $118(70.2)$ & $952(65.4)$ \\
\hline \multicolumn{6}{|l|}{ Region } \\
\hline West & $133(22.6)$ & $114(26.2)$ & $42(15.9)$ & $45(26.8)$ & $334(23.0)$ \\
\hline North & 118 (20.1) & $87(20.0)$ & $72(27.3)$ & $42(25.0)$ & $319(21.9)$ \\
\hline Serrana & $49(8.3)$ & $34(7.8)$ & $10(3.8)$ & $10(6.0)$ & $103(7.1)$ \\
\hline Vale do Itajá & $152(25.9)$ & $90(20.7)$ & $76(28.8)$ & $33(19.6)$ & $351(24.1)$ \\
\hline Greater Florianópolis & $97(16.5)$ & 80 (18.4) & $40(15.2)$ & $38(22.6)$ & 255 (17.5) \\
\hline South & $39(6.6)$ & $30(6.9)$ & $24(9.1)$ & $0(0.0)$ & $93(6.4)$ \\
\hline \multicolumn{6}{|l|}{ Population } \\
\hline$<99,999$ & $222(37.8)$ & $161(37.0)$ & $79(29.9)$ & $42(25.0)$ & $504(34.6)$ \\
\hline $100,000-499,999$ & $326(55.4)$ & $244(56.1)$ & $158(59.8)$ & $98(58.3)$ & $826(56.8)$ \\
\hline $500,000>$ & $40(6.8)$ & $30(6.9)$ & $27(10.2)$ & $28(16.7)$ & $125(8.6)$ \\
\hline \multicolumn{6}{|l|}{ HDI } \\
\hline Very high & $301(51.2)$ & $227(52.2)$ & $189(71.6)$ & $109(64.9)$ & $826(56.8)$ \\
\hline High & $287(48.8)$ & $208(47.8)$ & 75 (28.4) & $59(35.1)$ & $629(43.2)$ \\
\hline \multicolumn{6}{|l|}{ Semester of birth } \\
\hline $1^{1 \star s}$ semester & $350(59.5)$ & $246(56.6)$ & $152(57.6)$ & $98(58.3)$ & $846(58.1)$ \\
\hline $2^{\text {nd }}$ semester & $238(40.5)$ & 189 (43.4) & $112(42.4)$ & $70(41.7)$ & 609 (41.9) \\
\hline Total & $588(40.4)$ & $435(29.9)$ & 264 (18.1) & $168(11.5)$ & $1455(100.0)$ \\
\hline
\end{tabular}

\section{Statisical Procedure}

Descriptive statistics (absolute and relative frequency) provides data on the various aspects of the 
sample and the categories under analysis. The binary logistic regression model was used to verify the association between the dependent variable (call for selection) and the independent variables that can influence the call for selection (region, population, HDI and semester of birth). In the Binary Logistic Regression Equation, the value of $P$ means the probability of being summoned for selection, that is, that the value of $Y$ is 1 . The coefficients of the independent variables (â) represent the variations in units that impact the value of $P$ (logarithm of the odds ratio). The chi-square of the 0 mnibus Test was measured for each model and the Cox \& Snell's and Nagelkerke's R-square values were verified. The categorization of the RAE in the semester of birth was performed to meet the priority of the number of individuals per category in the logistic regression. A nalysiswere stratified according to category (u13, u15, u17), with three regression models. Analysis for category u19 was not performed since the state of Santa Catarina does not have the category. However, players' recruitments for previous teams were included and crude analyses were undertaken to verify the association between each independent variable and recruitment. Adjusted models were then employed and variables at $p$-value $<0.25$ in crude analysis were added (Field, 2011), the crude model was used to identify which variables could include the adjusted model. The reference categories were chosen according to what is proposed by Brown (2006). In addition, 0 dds Ratios (O Rs) and confidence intervals were calculated for all quartiles of birth and for the two semesters of the year. All statistical procedures were undertaken by IBM SPSS v. 20.0 (Inc, Chicago, IL, USA) at 5\% significance.

\section{Results}

0 Rs results are presented in Table 2. Based on previous studies (Ibãnéz et al. 2018), the samplerevealed significant ORs for the comparisons of the semester of birth of category u13, except in comparison of the 1st vs the 2 nd. However, the other categories did not have a significant relationship.

\footnotetext{
Table 2.

Unadjusted odds ratios (ORS) according to categories in Championship of the State of Santa Catarina examining relative age effect.

\begin{tabular}{lccccc}
\hline \multirow{2}{*}{ Categories } & \multicolumn{4}{c}{ OR comparison (Q 1-4/ 1 1st and 2nd 6 months) (95\% CI) } \\
\cline { 2 - 6 } & Q1 vs Q 4 & Q2 vs Q 4 & Q3 vs Q 4 & 1st vs 2nd & p-valor \\
\hline U13 & $4.56(3.75-4.90)$ & $3.23(2.70-3.89)$ & $3.76(2.36-5.98)$ & $1.89(0.45-3,80)$ & 0,001 \\
U15 & $2.84(1.76-4.56)$ & $1.60(0.97-2.65)$ & $2.53(0.68-3.69)$ & $1.63(0.53-2.79)$ & 0,198 \\
U17 & $1.11(0.70-1.75)$ & $0.94(0.59-1.50)$ & $1.18(0.75-1.86)$ & $1.68(0.62-2.57)$ & 0,108 \\
U19 & $1.60(0.74-3.45)$ & $2.05(0.96-4.34)$ & $0.85(0.36-1.95)$ & $1.70(0.43-3.72)$ & 0,145 \\
\hline
\end{tabular}
}

Table 3 provides an analysis of crude and adjusted logistic regression for conditions by which players would be recruited for state team u13. Crude analysis failed to show any association between region, population size and $\mathrm{HDI}$ of the city to which they were linked, and recruitment of the state team. However, RAE was confirmed, since early-birth players had a $72 \%$ more chance to be recruited for team u13 when compared to late-birth peers.

\begin{tabular}{|c|c|c|}
\hline \multirow[b]{2}{*}{ Variables } & \multicolumn{2}{|c|}{ U13 } \\
\hline & $\begin{array}{l}\text { Crude analysis } \\
\text { OR (CI95\%) }\end{array}$ & $\begin{array}{c}\text { Adjusted analysis } \\
\text { OR (CI95\%) }\end{array}$ \\
\hline \multicolumn{3}{|l|}{ Region } \\
\hline West & 1 & 1 \\
\hline North & $0.585(0.267-1.284)$ & $0.775(0.310-1.940)$ \\
\hline Serrana & $0.925(0.437-1.961)$ & $1.090(0.452-2.628)$ \\
\hline Vale do Itajál & $0.335(0.101-1.109)$ & $0.430(0.128-1.441)$ \\
\hline Greater Florianópolis & $0.720(0.336-1.540)$ & $0.562(0.242-1.307)$ \\
\hline South & $0.446(0.188-1.055)$ & $0.260(0.099-0.684)^{*}$ \\
\hline \multicolumn{3}{|l|}{ Population } \\
\hline Until 99.999 & 1 & 1 \\
\hline 100.000 a 499.999 & $1.079(0.434-2.680)$ & $2.326(1.333-4.058) *$ \\
\hline 500.000 or more & $2.039(0.869-4.785)$ & $0.481(0.172-1.345)$ \\
\hline \multicolumn{3}{|l|}{ HDI } \\
\hline High & 1 & 1 \\
\hline Very high & $1.463(0.972-2.200)$ & $1.811(1.098-2.987)^{*}$ \\
\hline \multicolumn{3}{|l|}{ Semester of birth } \\
\hline $1^{0}$ semester & $1.723(1.129-2.629)^{*}$ & $1.717(1.118-2.2635)^{*}$ \\
\hline 20 semester & 1 & 1 \\
\hline
\end{tabular}

Adjusted analysis reveal ed several modifications for theassociations. Players hailing from clubsin the southern region of the state had a 74\% less chance in being recruited for team u13 when compared with peers who train in the western region, regardless of all variables. M oreover, players from medium-sized cities $(100,000$ - 499,999) hasa2.32 fold morechance of being recruited when compared to players hailing from small-sized cities (> 99,999), regardless of region, HDI and RAE. Further, players who train in cities with very high HDI had a 1.81 fold more chance of being recruited for the state team, regardless of all variables. RAE was confirmed since early-birth players had a $72 \%$ more chance of being recruited when compared to peers born during the second semester, regardless of region, population and HDI of the city in which they practice.

The 0 mnibus Test verifies the hypothesis that all the regression model coefficients are null. The Chisquare value was 26.745 with a significance of 0.002 , so the model can explain the event. The results of $\mathrm{Cox} \&$ Snell and Nagelkerke's pseudo- $\mathrm{R}^{2}$ showed the proportion of variations that occurred in the logarithm of the odds ratio $(P)$, which is explained by the variations that occurred in the independent variables of the regression model. Cox \& Snell's $\mathrm{R}^{2}$ indicates that 44\% of the variations that occurred in the logarithm of the 
odds ratio are due to variations in the independent variables of the model. Similarly, Nagelkerke's $\mathrm{R}^{2}$ shows that independent variables influence $17.9 \%$ in variations in the logarithm of the odds ratio. The result of the Hosmer and Lemeshow test showsa Chi-square of 3.035 with a significance of 0.882 (sig > 0.05). This indicates that the predicted values are not significantly different from those observed, since the level of significance was greater than 0.05 . Therefore, the regression model can be used to estimate the probability of an athlete being called up for selection u13 according to the independent variables used.

Table 4 provides the results of crude and adjusted logistic regression for players recruited for State Team u15. Crude analysis revealed that region, population and HDI were associated with recruitment for state team, or rather, players that trained in the northern region have a 2.19 fold chance of being recruited for team u15 when compared to those of the western region. Players linked to medium-sized cities $(100,000$ 499,999 ) had a 1.81 fold chance of being called up when compared to peers in high HDI cities.

\begin{tabular}{|c|c|c|}
\hline \multirow[b]{2}{*}{ Variables } & \multicolumn{2}{|c|}{ U15 } \\
\hline & $\begin{array}{l}\text { Crude analysis } \\
\text { OR (CI95\%) }\end{array}$ & $\begin{array}{c}\text { Adjusted analysis } \\
\text { OR (CI95\%) }\end{array}$ \\
\hline \multicolumn{3}{|l|}{ Region } \\
\hline West & 1 & 1 \\
\hline North & $2.199(1.136-4.259) *$ & $0.479(0.153-1.494)$ \\
\hline Serrana & $0.224(0.029-1.725)$ & $0.998(0.367-2.713)$ \\
\hline Vale do Itajaí & $0.950(0.446-2.023)$ & $0.133(0.016-1.094)$ \\
\hline Greater Florianópolis & $0.933(0.407-2.136)$ & $0.288(0.103-0.808)^{*}$ \\
\hline South & $2.151(0.874-5.296)$ & $0.210(0.069-0.640) *$ \\
\hline \multicolumn{3}{|l|}{ Population } \\
\hline Until 99.999 & 1 & 1 \\
\hline 100.000 a 499.999 & $1.814(1.049-3.137) *$ & $1.924(0.953-3.882)$ \\
\hline 500.000 or more & $1.125(0.409-3.091)$ & $0.369(0.116-1.177)$ \\
\hline \multicolumn{3}{|l|}{ HDI } \\
\hline High & 1 & 1 \\
\hline Very high & $1.892(1.138-3.145)^{*}$ & $2.341(1.240-4.418)^{*}$ \\
\hline \multicolumn{3}{|l|}{ Semester of birth } \\
\hline 10 semester & $1.221(0.755-1.972)$ & $1.207(0.740-1.970)$ \\
\hline 20 semester & 1 & 1 \\
\hline
\end{tabular}

Adjusted analysis showed that only variables region and HDI were associated with recruitment for the State Team. However, adjustment changed the region's association categories, or rather, players of the Greater Florianópolis (72\%) and the South region (89\%) had less chances in being recruited for the StateTeam when compared to players from the west. In the case of HDI, besides the maintenance of the association, $O R$ rate increased and showed that players from cities with very high HDI had a 2.34 fold chance of being recruited than players of cities with high HDI, regardless of region, population and semester of birth.

In the 0 mnibus Test, the Chi-square value was 30,646 with a significance of 0.000 (sig.<0.05), that is, the model can explain the event. Cox $\&$ Snell's $R^{2}$ indicates that $68 \%$ of the variations in the logarithm of the odds ratio are due to variations in the independent variables of the model. Nagelkerke's $\mathrm{R}^{2}$ shows that independent variables influence $25.2 \%$ in the logarithm variations of the odds ratio. The result of the Hosmer and Lemeshow test shows a Chi-square of 0.043 with a significance of 1.000 (sig >0.05). Thus, the regression model can be used to estimate the probability that an athlete will be called up for selection u15 according to the independent variables used.

Table 5 gives the results of the analysis of crude and adjusted logistic regression for players being recruited for StateTeam u17. Crude analysis revealed that region, population and $\mathrm{HDI}$ of the city where the player trained were associated with recruitment, although RAE has not been proven. No association occurred in the adjustment of associations for all variables.

The values of the 0 mnibusTest were not significant (0.573), demonstrating that the model has low explanatory power for the event. Cox $\&$ Snell's R $^{2}$ indicates that $28 \%$ of the changes in the logarithm of the odds ratio are due to variations in the independent variables of the model. Nagelkerke's $R^{2}$ shows that the independent variables influence $65 \%$ in the logarithm variations of the odds ratio. The result of the Hosmer and Lemeshow test shows a Chi-square of 8.675 with a significance of 0.277 (sig >0.05). Thus, the regression model cannot be used to estimate the probability that an athlete will be called up for selection u17 according to the independent variables used.

\begin{tabular}{|c|c|c|}
\hline \multirow[b]{2}{*}{ Variables } & \multicolumn{2}{|c|}{ U17 } \\
\hline & $\begin{array}{l}\text { Crude analysis } \\
\text { OR (C195\%) }\end{array}$ & $\begin{array}{c}\text { Adjusted analysis } \\
\text { OR (CI95\%) }\end{array}$ \\
\hline \multicolumn{3}{|l|}{ Region } \\
\hline West & 1 & 1 \\
\hline North & $4.644(1.545-13.956) *$ & $2.083(0.204-21.212)$ \\
\hline Serrana & $0.000(0.000)$ & $7.585(0.868-66.287)$ \\
\hline Vale do Itajaí & $2.920(0.932-9.147)$ & $0.000(0.000)$ \\
\hline Greater Florianópolis & $3.367(1.044-10.863)^{*}$ & $3.854(0.465-31.915)$ \\
\hline South & $0.897(0.099-8.121)$ & $3.676(0.418-32.297)$ \\
\hline \multicolumn{3}{|l|}{ Population } \\
\hline$>99,999$ & 1 & 1 \\
\hline $100,000-499,999$ & $0.279(0.092-0.846) *$ & $2.506(0.966-6.504)$ \\
\hline 500,000 and $<$ & $0.773(0.316-1.893)$ & $1.396(0.386-5.045)$ \\
\hline \multicolumn{3}{|l|}{ HDI } \\
\hline High & 1 & 1 \\
\hline Very high & $2.072(1.059-4.057) *$ & $1.141(0.527-2.469)$ \\
\hline \multicolumn{3}{|l|}{ Semester of birth } \\
\hline $1^{\text {st }}$ semester & $0.649(0.356-1.183)$ & $0.610(0.333-1.120)$ \\
\hline $2^{\text {nd }}$ semester & 1 & 1 \\
\hline
\end{tabular}

\section{Discussion}

Current study analyzed the prevalence of RAE in basketball players to verify whether early-birth players and the characteristics of players' city in which they 
were inserted affected the probability of being recruited for State Leagues. Data revealed that sample is predominantly composed of early-birth young people. Evidence partially confirms the study's first hypothesis and agrees with several other analyses in the literature which show a high representation of players born within the first six months of the years, in basketball (Arrieta et al., 2016; Ibãnéz et al., 2018) and in other sports modalities (Leonardo, Lizana, Krahenbühl \& Scaglia, 2018; Huertas et al., 2019; Jackson \& Comber 2020).

Results also revealed that early-birth u13 players had greater recruitment chances for State Leagues when compared to late-birth peers. Results are consistent with other studies on basketball which demonstrate a greater RAE influence on younger categories when players are recruited due to maturity associated mainly with height, weight and strength (Delorme \& Raspaud 2009). In a study with French young people, results showed that late-birth players were simultaneously subrepresented and significantly smaller than early-birth ones (Delorme \& Raspaud 2009). In the abovementioned case, effect is associated with temporary advantages in participation and performance of chronologically older players when compared to young ones within the same age group (Brustio et al. , 2019; Ibãnéz et al., 2018).

Evidences in the literature suggest that RAEdetermined player recruitment during youth is not a sine qua non condition for a successful future in sports (W rang et al., 2018). W hy this occurs in long-term sports development has been greatly discussed (Webdale, Baker, Schorer \& Wattie, 2019). A study by Barreiros et al. (2014) concluded that younger players had more re-recruitment chances at a national level when compared to older ones. McCarthy \& Collins (2014) detected a benefit reversal of RAE since relatively younger players in the English rugby team and in the Canadian ice hockey were greatly represented in elite leagues. Probably younger players were motivated to improve their intelligence in matches and development abilities (resilience, mental resistance, cognitive-perceptive capacities) that make them capable of competing with older peers and overcome chronological limitations (Huertas et al., 2019). Such abilities may help them to have a better sports performance as adults since advantages based on date of birth tend to disappear or they do not remain so much evident as players age (García, Aguilar, Romero, Lastra \& Oliveira, 2012).

Moreover, results showed that $u 15$ and $u 17$ players have similar chances of being recruited for the State League regardless of their birthday. Further, a gradual decrease has been detected in the number of players who competed for the Championship of the state of Santa Catarina in both categories. Indexes are very similar to those from other states, or rather, a progressive decrease in the performance and number of players (Jackson \& Comber 2020) during the transition for older categories (Brustio et al. , 2019). However, they oppose results reached by García et al. (2012) and by O liveira et al. (2017), whose u15, u16 and u17 categories were predominantly composed of early-birth players. Since the characteristics or motives for such a reduction were not forthcoming, one may hypothesize that older players were the first to give priority to other affairs in their lives and thus quitted sports as they became older (Jackson \& Comber 2020) to devote themselves to studies or other professional activities.

It seems that swimming and table tennis are not influenced by RAE (Faber, Lui, Cece, Jie, Martinent, Schorer \& Elferink-Gemser, 2019). According to these authors, the absence of RAE may be explained by greater requirements in the technical-motor abilities that these sportsmodalities demand and by less attention of coaches to the players' anthropometric and maturity factors. However, the above-mentioned studies dealt with events in Sweden and Holland where sports formation programs are traditionally developed with emphasis on technical quality and specific motor abilities (Faber et al., 2019). O $n$ the other hand, RAE proved to be strong in Russian soccer from young to elite categories (Bezuglov et al., 2019). In the world basketball championship, RAE became evident in u17 and $u 19$ players (García et al., 2012), contrary to what has been detected in current study with regard to the u17 category.

On the other hand, RAE has a smaller prevalence rate in countries with a weak athletic culture and a reduced number of people interested in sports. According to Campos, Pellegrinotti, Campos, Dias \& Gómez (2020), there was a more equal distribution in African elite players' birth quartiles when compared to those in Asia, America and Europe. Consequently, several factors related to the individual players' attributes (birthdate, maturity), task (type of sports, competition level) and environment (sports system in categories, sports culture, demographic characteristics) interact in favor of RAE.

Another relevant aspect is the players' place of training which, in current study, is the club's geographic 
region. Results showed that players linked to clubs in the Greater Florianópolis and in the south region of the state have less chance for recruitment for the $u 13$ and u15 leagues when compared to peers in the west of the state. Although our results may not be related to other studies, it should be underscored that Santa Catarina has been highlighted in the formation of basketball players. Established in 1995, the FCB has had its level raised year by year and has become one of the most robust of sports federations, with numerous teams in Brazil (Silva, 2019). In 2018, the FCB organized more than 20 competitions and approximately 1,500 matches with players ranging between u12 and adult groups, comprising state championships and interstate tournaments. There were 203 teams in state championships (FCB, 2018), whilst in 2019 there were 189 teams and approximately 1,300 matches (FCB, 2019).

Six sports clubs have been established in the western region of the state of Santa Catarina, most of them affiliated to the FCB since 2005. Perhaps one of the motives that players from this region have great possibilities in being recruited for state leagues lies in the fact that sports clubs, especially the Chapecó club, are already well-established sports institutions within the state. Since players belong to reference institutions, with directories notorious for their sports organization and development, their chances of growth have increased and their identification by league agents in the state has been favored. A study on young Irish soccer players concluded that players in reference centers had 50\% more chances of being recruited at high sports levels than playersfixed in other centers (Rossing et al ., 2018). $0 \mathrm{n}$ the other hand, the eight clubs in the Greater Florianópolis and in the south region of the state are more recent institutions, affiliated to theFCB since 2012, with the exception of the pioneer club of the capital city affiliated in 1995 (FCB, 2019).

The influence of culture and social structure of the local community with regard to the sports club is also a relevant factor (Baker et al., 2009). Evidence shows that the greater is the collective identity to the group, the greater is the capacity to cooperate and show reciprocity with its members (Balish \& Côté 2013). Eventually smaller communities are likely to be more cohesive and become a constructive context for such identity (Balish \& Côté 2013). Since most sports clubs in the west of the state of Santa Catarina are established in small towns and cities, this fact may have triggered a favorable milieu for the formation of players with a deep sense of belonging and, coupled to the clubs' formative acknowledgement, may have encouraged the sports trends of young people.

Results from crude analysis evidenced that players who train in the north region have still more chances of being recruited for u15 leagues when compared to players in the west. Although such association has not been corroborated by corrective adjustment analysis, it should be underscored that the northern region of the state of Santa Catarina has been in the limelight within and outside the state with regard to basketball formation and training. In fact, the region is rife with consolidated sports clubs and with a long history of affiliation to $F C B$, besides exhibiting highly competitive teams, mainly in the cities of Joinville and Jaraguá do Sul. These two cities are the headquarters of seven of the regions ten teams. In the last three years (2017, 2018,2019 ) they participated in the Liga Nacional de Basquete[N ational Basketball League] (LigaO uro), N ovo Basquete Brasil [New Basketball Brazil] (NBB), Campeonato Brasileiro de Basquete Masculino [National Men's Championship League] and the Liga de Basquete Feminino [Women's Basketball League] (LBF), besides state and interstate competitions in all categories. Sports clubs of other regions of the state failed to have such attributes. W hen sports structures for the aggregation of promising young people are made possible for higher competitivelevels (for instance, adult teams representing the city at international level), the clubs are stimulating the idea of continuity and growth in the sports modality within their own city (Balish et al., 2015).

Results on the demographic feature of the training community of players from the state of Santa Catarina are consistent to current study's second hypothesis. Players from very high HDI middle-sized cities have more chances to be recruited for state leagues when compared to players from small-size cities with high HDI. The above results foreground previous studies that highlight middle-size cities as a favorable milieu for matches, participative and competitive experiences, particularly in the first years of sports engagement (Baker et al., 2009). Further, slightly bigger cities may provide better conditions for sports practice, such as better projected and equipped sporting centers (with arenas, fields, swimming pools) and more experienced coaches. Results are consistent to data retrieved from Brazilian Olympic players (Tozetto et al., 2017), but inconsistent with data on Danish players (Rossing, Nielsen, Elbe \& Karbing, 2016).

Data in the literature suggest that small cities may 
be at a disadvantage due to lack of funding and few people involved in sports participation and training (Baker et al., 2009). O n the other hand, several researchers report that these cities have greater mobility and physical safety, a greater integrative approach among different contexts (sports, school, family, community) and favor a better personal relationship among players and coaches (Côté et al., 2006). It is true that such evidences represent different population distributions inherent to each country (Baker et al., 2009). Although results suggested that players from the state of Santa Catarina have less probability in being recruited for state leagues when linked to small or to very big cities, there are exceptions among the different contexts.

Similar to other transversal researches, current study fails to make an analysis with the same players in other FCB leagues and seasons. Further, the motives that led to the recruitment of early-birth players have not been investigated, or rather, whether they may be linked to excellent physical and motor abilities or to technical and tactical skills to determine what actually was underscored when compared to late-birth players.

In spite of these limitations, data may contribute towards further discussions on the influence of RAE and local features within the context of player recruitment for state leagues. Further research is required to better understand the different consequences of the RAE phenomenon in the sportsformation of young players and their implications for the performance and selection of talented people. Coaches, federations and confederationsare recommended to acknowledge RAE, the variables linked to the phenomenon and its possible consequences, so that recruitment of the modality advances and the early exclusion of players from the long formative process is avoided.

\section{Conclusion}

We concluded that the early-birth basketball players had greater recruitment chances for state teams u13 than late-birth ones. Further, players u15 and u17 had similar chances for recruitment, regardless of the date of birth. Players $u 13$ and $u 15$ hailing from the north region from Brazil and from cities with very high HDI or medium-sized cities had better recruitment chances for participating in basketball teams in Santa Catarina. O ver time and as our data suggests, the disadvantage is likely to diminish, however other factors are likely to become more influential and worrying. Thus, it seems that RAEs reflect a type of developmental barrier of young players one which is preventable if appropriate solutionswill be implemented. Therefore, policy changes regarding age selection rules of players of the Championship Basketball of the State of Santa Catarina may affect the RAE prevalence, as the phenomenon was observed to occur at the U 13 categories, the second youngest category in the state. Besides that, corrective adjustments may hold significant implications for current youth sport contexts mainly in team sports.

\section{Acknowledgment}

Thanks are due to the Santa Catarina Federation of Basketball (FCB) for making the data available; to Walan Robert da Silva for his assistance with statistics; and to the members of LAPRAPEF for their assistance and participation in current research.

\section{Funding}

This study was financed in part by the Coordenação de Aperfeiçoamento de Pessoal de Nível Superior Brasil (CAPES) - Finance Code 001.

\section{References}

Arrieta, H.,Torres-Unda, J., Gil, S. M., \& Irazusta, J. (2016). Relative age effect and performance in the U16, U18 and U20 European Basketball Championships. Journal of Sports Science, 34(16), 1530-1534. https:/ / doi.org/ 10.1080/02640414.2015. 1122204

Baker, J., \& Horton, S. (2004): A review of primary and secondary influences on sport expertise. High Ability Studies, 15(2), 211-228. https:/ / doi.org/ 10.1080/ 1359813042000314781

Baker, L., \& Logan, J. A. (2007). Developmental contexts and sporting success: birth date and birthplace effects in national hockey leaguedrattees2000-2005. British Journal of Sports M edicine, 41 (8), 515-517. https:/ / doi.org/ 10.1136/ bjsm. 2006.033977

Baker, J., Schorer, J., Cobley, S., Schimmer, G., \& Wattie, N. (2009). Circumstantial development and athletic excellence: The role of date of birth and birthplace. European Journal of Sport Science, 9(6), 329-339. https:/ / doi.org/ 10.1080/ 17461390902933812

Balish, S. M . \& \& Côté, J. (2013). Theinfluence of community on athletic development: an integrated case study. Qualitative Research in Sport, Exercise and Health, 6(1), 98120.https/ / doi.org/ 10.1080/ 2159676x.2013.766815 Balish, S. M., Rainham, D., \& Blanchard, C. (2015). 
Community size and sport participation across 22 countries. Scandinavian Journal of Medicine $\&$ Science in Sports, 25(6), e576-581. https:/ / doi.org/ 10.1111/ sms. 12375

Barreiros, A., Cote, J., \& Fonseca, A. M. (2014). From early to adult sport success: analysing athletes' progression in national squads. European Journal of Sport Science, 14(1), 178-182.https: / / doi. org/ 10.1080/ 17461391.2012 .671368

Bezuglov, E. N., Nikolaidis, P.T., Khaitin, V., Usmanova, E., Luibushkina, A., Repetiuk, A., Knechtle, B. (2019). Prevalence of Relative Age Effect in Russian Soccer: The Role of Chronological Age and Performance. International Journal of Environmental Research and Public Health, 16(21). https:// doi.org/ 10.3390/ ijerph16214055

BidaurrazagazLetona, I., Badiola, A., Granados, C., Lekue, J. A., Amado, M., \& Gil, S. M. (2015). Efecto relativo delaedad en futbol: estudio en un clubVasco profesional (Relative age effect in soccer: a study in a professional Basque club). Retos, 25, 95-99. https:/ / doi.org/ 10.47197/ retos. v0i25.34489

Brown,T.A. (2006). Confirmatory FactorAnalysisforApplied Research. New York, NY:The Guilford Press.

Brustio, P. R., Kearney, P. E., Lupo, C., Ungureanu, A. N., Mulasso, A., Rainoldi, A., \& Boccia, G. (2019). Relative ageinfluencesperformance of world-classtrack and field athletes even in the adulthood. Frontiers in Psychology, 10(1395), 1-9. https:// doi.org/ 10.3389/ fpsyg2019.01395

Campos, F. A. D., Pellegrinotti, I. L., Campos, L. C. B., Dias, T. M. R., \& Gómez, M. A. (2020). Relative age effect in the girls' volleyball u18 world championship. Journal of Human Kinetics, 72, 195-202. https:/ / doi.org/ 10.2478/ hukin-2019-0106

Côté, J., M acdonald, D. J., Baker, J., \&A bernethy, B. (2006). When «where» is more important than «when»: birthplace and birthdate effects on the achievement of sporting expertise. Journal of Sports Science, 24(10), 10651073. https:/ / doi.org/ 10.1080/ 02640410500432490

Carraco, D. S, Galatti, L. R., M assa, M ., Loturco, I., \&Abad, C. C. C. (2020). Centesimal Age and RelativeAge Effect in Elite Futsal Players. International Journal of Exercise Science, 13(6), 329-341.

Delorme, N., Boiché, J., \&Raspaud, M. (2010). Relative age effect in elite sports: Methodological bias or real discrimination? European Journal of Sport Science, 10(2), 91-96. https/ / doi.org/ 10.1080/ 17461390903271584

Delorme, N., \& Raspaud, M. (2009). The relative age effect in young French basketball players: astudy on the whole population. Scandinavian Journal of Medicine $\&$ Science in Sports, 19(2), 235-242. https:/ / doi.org/ 10.1111/ j.16000838.2008.00781.x

Faber, I. R., Liu, M., Cece,V., Jie, R., Martinent, G., Schorer, J., \&Elferink-Gemser, M. T. (2019). The interaction between within-year and between-year effects across ages in elite table tennis in international and national contexts - A further exploration of relative age effects in sports. High Ability Studies, 1-14. https:/ / doi.org/ 10.1080/ 13598139.2019.1596071

FCB. (2018). Revista FCB - Basquete SC. 11․ https:// issuu.com/ fcb-basket/ docs/ basquetesc. 011/ s/ 29595

FCB. (2019). Revista FCB - Basquete SC. 15‥ http:// issuu.com/ fcb-basket/ docs/ basquetesc. 015

Field,A. (2011). Discovering Statisics (4 ed. ). London, England: Sage Publications (CA).

Fumarco, L., Gibbs, B. G. , Jarvis, J. A., \& Rossi, G. (2017). The relative age effect reversal among the National Hockey Leagueelite. PLoS One, 12(8), e0182827. https:/ / doi.org/ 10.1371/ journal. pone. 0182827

García, M. S., Aguilar, O. G., Romero, J. J. F., Lastra, D. F., $\&$ O liveira, G. E. (2012). Relative age effect in lower categories of international basketball. International Review for theSociology of Sport, 49(5), 526-535. https: / / doi. org/ $10.1177 / 1012690212462832$

Huertas, F., Ballester, R., Gines, H. J., Hamidi, A. K., Morda, C., \& Lupianez, J. (2019). RelativeAge Effect in the Sport Environment. Role of Physical Fitness and Cognitive Function inYouth Soccer Players. International Journal of Environmental Research and Public Health, 16(2837), 1-19. https:// doi.org/ 10.3390/ ijerph16162837

Ibãnéz, S. J., Mazo, A., Nascimento, J., \& GarcíaRubio, J. (2018). The RelativeAge Effect in under-18 basketball: Effects on performance according to playing position. PLoS One, 13(7), e0200408. https:/ / doi.org/ 10.1371/ journal.pone. 0200408

Jackson, R. C., \& Comber, G. (2020). Hill onamountaintop: A longitudinal and cross-sectional analysis of the relative age effect in competitive youth football. Journal of Sports Science, 1, 1-7. https:/ / doi.org/ 10.1080/ 02640414.2019 .1706830

Katsumata, Y., O muro, K., Mitsukawa, N., \& Nakđa, H. (2018). Characteristics of Relative Age Effects and Anthropometric Data in Japanese Recreational and Elite Male Junior Baseball Players. Sports M ed Open, 4(52), 1-9. https:/ / doi.org/ 10.1186/ s40798-018-0165-9

Leonardo, L., Lizana, C. J. R., Krahenbühl, T., \& Scaglia, A. J. (2018) 0 efeito da idade relativa influencia o tempo de participação competitiva de atletas de handebol do 
sexo masculino com até 13 anos de idade. Retos. Nuevas tendencias en Educación Física, Deportey Recreación, 33, 195 198.

Mendes, C., Menegassi, V. M., Jaime, M. O., Costa, L. C. A., Marques, P. G., Rechenchosky, L., Rinaldi, W., \& Borges, P. H. (2021). Impacto do tamanho corpora, da idade relativa e do índice de desenvolvimento humano sobre aparticipação de futebolistas brasileiros na Liga dos Campeões da UEFA. Retos. Nuevas tendencias en Educación Físca, Deportey Recreación, 39, 271-275.

McCarthy, N., \& Collins, D. (2014). Initia identification \& selection bias versus the eventual confirmation of talent: evidence for the benefits of a rocky road? J ournal of Sports Science, 32(17), 1604-1610. https:/ / doi.org/ 10.1080/ 02640414.2014 .908322

Muñoz, A., González, C. S., Q uintana García, I., Peinado, M. G. (2021). Efecto relativo de la edad en el circuito profesional de Pádel The relative age effect in the professional Padel circuit. Retos. Nuevastendencias en Educación Física, Deportey Recreación, 41, 519-523.

Oliveira, H. Z., Ribeiro Júnior, D. B., Vianna, J. M., \& Werneck, F. Z. (2017). Efeito da idade relativano Campeonato Brasileiro deBasquete: categoriasub-15. Brazilian Journal of Kinanthropometry and H uman Performance, 19(5), 526-534. https:// doi.org/ 10.5007/ 19800037.2017v19n5p526

Papadopoulou, S. D. , Papadopoulou, S. K., Rosemann, T., Knechtle, B. \& \&Nikolaidis, P.T. (2019). Relative age effect on youth female volleyball players: a pilot study on its prevalence and relationship with anthropometric and physiological characteristics. Frontiers in Psychology, 10(2737), 1-9. https:/ / doi.org/ 10.3389/ fpsyg.2019.02737

Programa das Nações Unidas para o Desenvolvimento no Brasil (PNUD). (2019) Atlas do Desenvolvimento Humano no Brasil 2013. Retrivied Febreary 16, 2021, from https:/ / www. br. undp.org/ content/ brazil/ pt/ home/ idho/ atlas-do-desenvolvimento-humano/ atlas-dosmunicipios. html

Ramos-Filho, L.,\& Ferreira, M. P. (2020).The reverse relative age effect in professional soccer: an analysis of the Brazilian National League of 2015. European Sport Management Quarterly, 21(1), 78-93. https:/ / doi;org/ $10.1080 / 16184742.2020 .1725089$

Ribeiro Júnior, D. B. , Lobão, P. H. F., Oliveira, H. Z., Viana, J. M., \&Werneck, F. Z. (2020). 0 efeito da idade relatva em indivíduos normoestaturais e de elevada estatura no basquetebol de base do Brasil. E-Balonmano. com: Revista deCienciasdel D eporte, 16(1), 1-10.

Rossing, N. N., Nielsen, A. B., Elbe, A. M., \&Karbing, D. S.
(2016). The role of community in the development of elite handball and football players in Denmark. European Journal of Sport Science, 16(2), 237-245. https:/ / doi.org/ 10.1080/ 17461391.2015. 1009492

Rossing, N. N., Stentoft, D., Flatum, A., Côté, J., \&Karbing, D. S. (2018). Influence of population size, density, and proximity to talent clubs on the likelihood of becoming elite youth athlete. Scandinavian Journal of Medicine \& Science in Sports, 28(3), 1304-1313. https:/ / doi.org/ 10.1111/ sms. 13009

Rubajczyk, K., Swierzko, K. , \&Rokita, A. (2017). Doubly Disadvantaged?The RelativeAge Effect in Poland's Basketball Players. Journal of SportsSciencesand M edicine, 16(2), 280-285.

Silva, S. 2019. 3 Décadas de amor ao basquete. https:/ / www. esportesc. com/ detalhes/3-decadas-de-amor-aobasquete-apos-mudar-cenario-da-modalidade-no-estadooscar-archer-encerra-ciclo-de-conquistas-e-realizacoesafrente-da-presidenciadafcb-6931/

Tozetto, A. V. B., Rosa, R. S. D., Mendes, F. G., Galatti, L. R., Souza, E. R. D., Collet, C., Silva, W. R. D. (2017). Loca denascimento edatadenascimento demedalhistas olímpicos brasileiros. Brazilian Journal of Kinanthropometry and H uman Performance, 19 (3), 364-373. https:/ / doi.org/ 10.5007/ 1980-0037.2017v19n3p364

Valero, A. F., Pérez, S. S. , Jaén, M. G. \& \&Anta, R C. (2020). Efecto de la edad relativa para el desarrollo del talento en jóvenes triatletas. Retos. Nuevas tendencias en Educación Físca, Deportey Recreación, 37, 27-32.

Webdale, K., Baker, J., Schorer, J., \& Wattie, N. (2019). Solving sport's 'relative age' problem: a systematic review of proposed solutions. International Review of Sport and Exercise Psychology, 1-18. https:/ / doi.org/ 10.1080/ $1750984 \times .2019 .1675083$

W rang, C. M., Rossing, N. N., Diernaes, R. M., Hansen, C. G., Dalgaard-Hansen, C., \& Karbing, D. S. (2018). RelativeAge Effect and the Re-Selection of Danish Male Handball Players for National Teams. Journal of Human Kinetics, 63, 33-41. https/ / doi.org/ 10.2478/ hukin-20180004

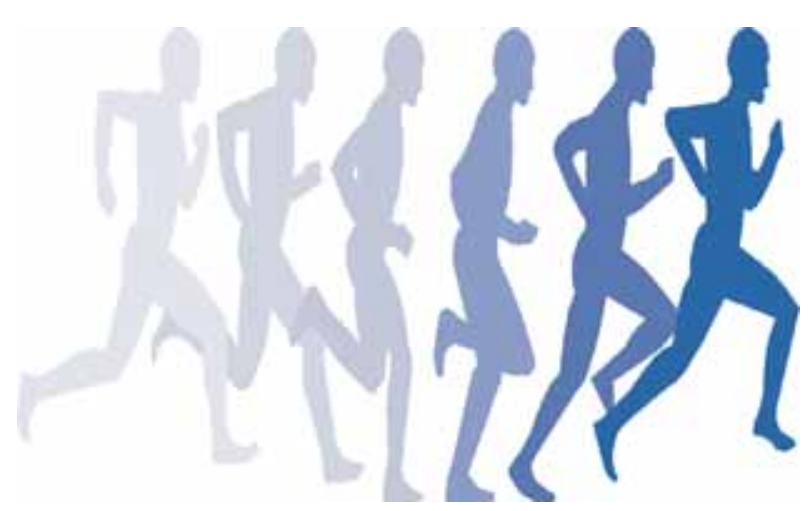

